Zoran M. Karastojković ${ }^{*}$, Suzana R. Polić ${ }^{2}$, Slobodan B. Čubrilović ${ }^{3}$, Danijela N. Jovanović ${ }^{2}$, Zoran V. Janjušević ${ }^{4}$, Aleksandra S. Patarić ${ }^{4}$

${ }^{1}$ Technical college, Novi Beograd, Serbia, ${ }^{2}$ Central institute for conservation, Belgrade,Serbia, ${ }^{3}$ Techcon, Novi Beograd,Serbia, ${ }^{4}$ University of Belgrade, Institute for technology of nuclear and other mineral raw materials, Belgrade, Serbia
Scientific paper

ISSN 0351-9465, E-ISSN 2466-2585

UDC: $620.193 .6 / .7$

doi:10.5937/ZasMat1803454K

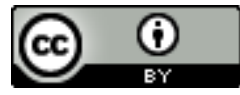

Zastita Materijala 59 (3)

454 - 458 (2018)

\title{
Corrodive cracks from flux residuals after brazing of thin leaves at an artistic desk lamp
}

\begin{abstract}
Making of an artistic piece usually includes a number of different technologies. It implies that for understanding of eventually present irregularities one should knows a lot of technical details. Brazing tehnology is one of them, inspection of integrity, also. Brazing technology generally has evolved on empirical manner, mainly by trial and error(s). The basic difficulty in this technology is that the real situation is highly complex due to the presence of large number of variables, some of them may not be easy to recognize. The great problem is the appearance of crack(s) in postcleaning periode, i.e after brazing is finished, it means over years or decades. A good braze joint must be both physically and chemically bounded.

One of the available method for investigation is radiographic testing, when the thickness of testing components commonly does not represents a problem. Here provided radiographic testing has revealed the existence of some indications only at leaves. The indications usualy mean discontinuity in material homogenity. Penetrant testing is a next step for investigation of surface. Registration of indications and their locations are necessary steps in any further approach for removing such discontinuities. Choosing the repair method always is particular problem, however in entire technique, especially on sensitive artistic component(s). Every action in repairing or restauration may led to more or less visible traces. Unadequate actions may permanently change the appearance or usage of treated artefact. Here is shown one irregularity (crack) at one brazed leaf from an artistic desk lamp.
\end{abstract}

Keywords: artistic piece, radiographic\&penetrant testing, corrosion crack.

\section{INTRODUCTION}

Even the earliest forms of metalworking sometimes need joint(s). Archeological evidence shows that brazing has been practiced continuosly since ancient times [1]. A few brazing methods did not belong a modern technologies, but some of them as like induction or laser brazing, however does.

Brazing of gold and silver using foils of copper and copper alloyed with more precious metals has been practiced to about 3000 years B.C. Abundant evidence of brazing, being used as a joining method, has been registered from objects dated from the Roman Imperial period. Pliny the Elder (1st century A.D.) mentioned one more version of bra

${ }^{*}$ Corresponding author: Zoran M. Karastojković

E-mail: zoran.karastojkovic@gmail.com

Paper received: 15. 05. 2018.

Paper accepted: 17. 06. 2018.

Paper is available on the website:

www.idk.org.rs/journal zing methods, used in antiquity for joining gold granules to gold sheet: a powdered copper-bearing ore (such as malachite) is heated with a flux in a reducing environment. This operation yielded alloying of copper with more noble metal, and obtaining a brazed joint. Thus, brazing in its most traditional form takes advantage: the melting point of copper after alloying with gold and silver is below that of all three individual metals [2,3].

The concept of brazing is that the base metal does not have to be melted, and that fact offers several advantages over other welding technologies. Even more, brazing makes it possible to join dissimilar metals (also metal to ceramics) that, because of metallurgical incompatibilities, cannot be joined by any traditional fusion welding processes. Lower working temperatures produces less thermally induced distorsion than fusion welding [4-6].

As in other welding processes, brazing also produces a heat affected zone (HAZ). In that zone is strongly altered the miscrostructure as a result of 
temperature changes but also intensive mutual mass transfer between base and filler metal. The change of microstructure may have lead the change of mechanical properties of the entire joint. Corrosion atacks of used flux also may have lead to change the properties of joint, even damage of a whole part [5].

Those factors are leading to the appearance of crack(s) in the joint. If the crack is registered just after brazing process is finished, it is immediatly visible and of course could be removed $[7,8]$. The problem is more complex when $\operatorname{crack}(\mathrm{s})$ begun visible after a long period, as sometime happened in artistic components.

\section{ABOUT INVESTIGATED DESK LAMP}

Here investigated desk lamp from XIX century is designed by French artist Auguste Moreau. Two views of investigated desk lamp, $41 \mathrm{~cm}$ hight, are shown in Figs. 1a and b. Before providing any kind of testing the desk lamp is however visually inspected.

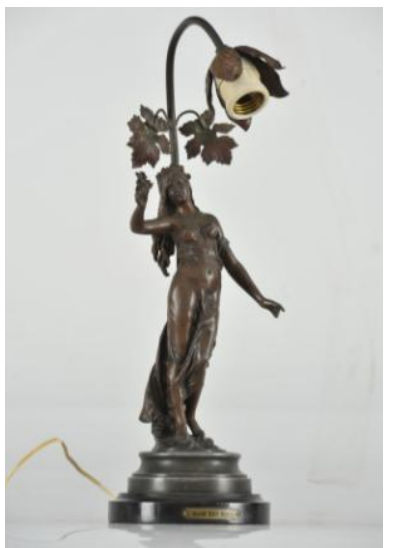

a)

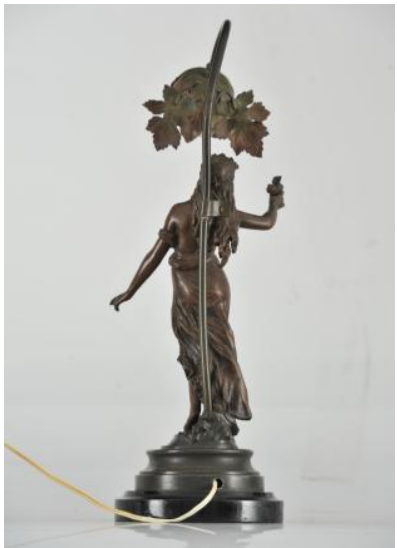

b)
Figure 1. Front a) and back) b) view of investigated desk lamp, end of XIX century [9]

Slika 1. Pogled spreda a) i otpozadi b) ispitivane stolene lampe, s kraja XIX veka

The investigated desk lamp is produced by casting, brazing and mechanical operations, while the surface is (electro)chemically treated to be corrodive resistant and for decorative reasons. The complex shaped body of desk lamp is produced by casting from zinc casting alloy $(\approx 90 \% \mathrm{Zn})$, with copper as a major alloying element. Thin leaves, about $1 \mathrm{~mm}$ in thickness, from the investigated desk lamp, could not be produced by casting method but using a kind of deforming method [6]. The hammering of those leaves is predicted to be potential method for their shaping. The hammered leaves further are brazed onto the central arm of desk lamp.

\section{BRAZING}

The quality of brazed joints depends strongly from: surface state, design of joint type, brazing gap, combination of filler/component materials and used flux. Both chemical and metallurgical changes that occur in making the brazing joint are vital for developing reliable joining process [7].

A brazed joint is usually required to satisfy a set of requrements, ordinary it means achieving the mechanical integrity and corrosion resistance. Mechanical integrity here means satisfying the strength of brazed joint and without crack(s). Small artistic components usually have no emphasized strength reguirements but they should have a good corrosion resistance in a long servicing time.

The geometry of the braze joint is also a crucial factor to be considered $[7,10]$. Brazing joint differs from a weld joint, Fig. 2a. The possible geometry of components to be brazed is shown in Fig. $2 b$.
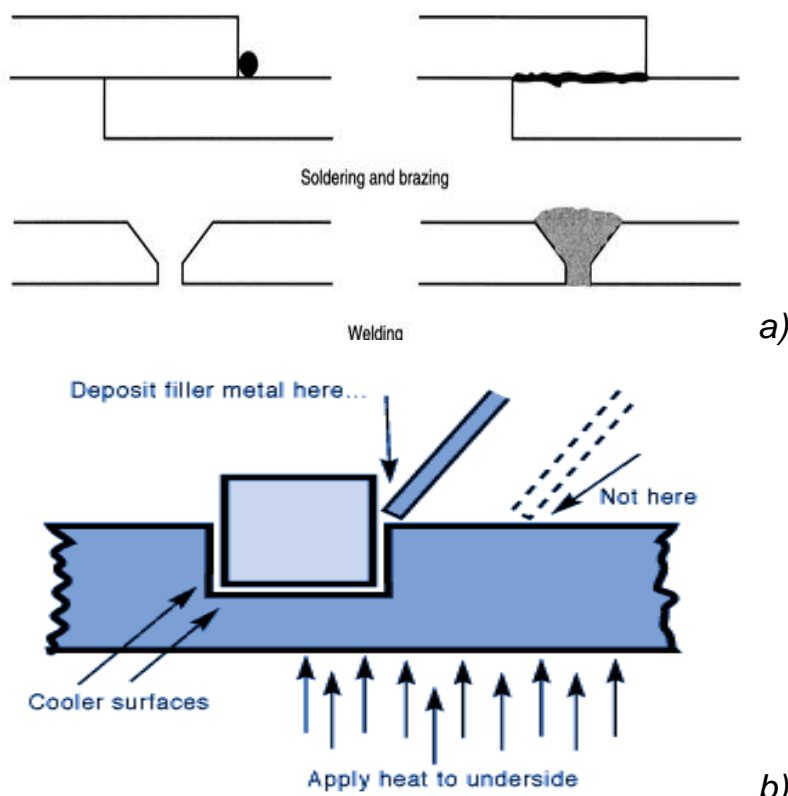

b)

Figure 2. Scetch of components for: a)

brazing/soldering and welding; and b) some recomendations in manual brazing and proposed heating direction

Slika 2. Skica delova za: a) lemljenje (tvrdo ili meko) $i$ varenje; $i$ b) neke preporuke pri ručnom

lemljenju i preporučeni način zagrevanja

Heating direction should not be direct onto the filler rod but at opposite side, just as shown in Fig. $2 b)$. The heated assembly will melt off a portion of the filler metal, so by capillary action this melt will be drawn to the entire area. For successful wetting, the base metal must be at least partially soluble in at least one component of the brazing alloy. The molten alloy therefore tends to attack the base metal and dissolve it, slightly changing its 
composition in the process. The composition change is reflected in the change of the alloy's melting point and the corresponding change of fluidity. For example, some alloys dissolve both silver and copper; dissolved silver lowers their melting point and increases fluidity, but copper has the opposite effect.

\section{PROVIDED TESTING}

Here are provided two testing methods, of interest for understanding the kind and a reason for type of corrosion crack found at investigated desk lamp.

\subsection{X-Ray transparent testing}

The image recorded on photo plate by using $X$ ray transparent technique is shown in Fig. 3 . At those leaves are visible indications as a thiny $(\approx 0.5 \mathrm{~mm}$ or less) white curved lines.

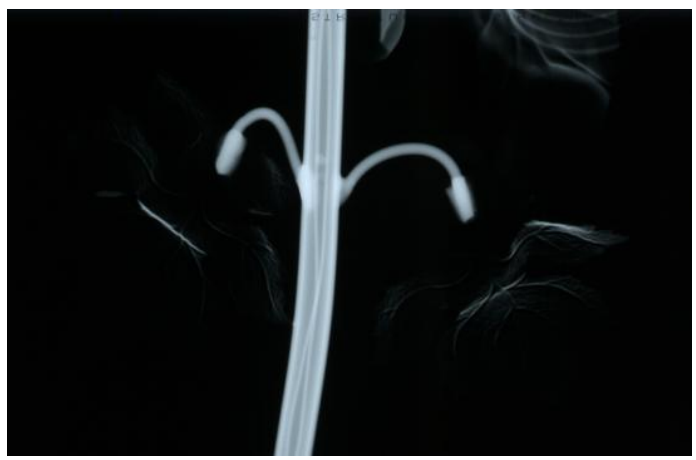

Figure 3. Negative of X-ray film at central part of desk lamp with leaves ( $\approx 1 \mathrm{~mm}$ in thickness) [9]

Slika 3. Negativ rendgenskog filma na centralnom delu stolne lampe sa listovima (debljine $\approx 1 \mathrm{~mm}$ ) [9]

From such film still is not clear what kind of hair discontinuities are. Those indications need more detail analyse by applying another testing methods [10-14], without destroying a tested component.

\subsection{Penetrant testing}

Penetrant testing (also known as liquid penetrant inspection) is used for more precise detecting of surface defects after casting, forging and welding, rarely in brazing. Surface porosity and defects as hairline cracks could be successfully registered by this testing method $[13,14]$. The procedure in liquid penetrant testing is pretty simple, the surface firstly is degreased and than sprayed with red suspension, Fig. 4a.

The red suspension fullfills eventualy present surface cracks, which begun visible in the third stage of such testing, when contrast arrises. As could be seen from Fig. 4b, there are no remains of red suspension. It means that at leaves were not registered the presence of cracks, carefully see
Fig. 4b. Such detail information could not be found by using $\mathrm{X}$-ray transparent inspection. So, revealing of crack(s) the using of X-ray transparent inspection has shown an uncertain effect.
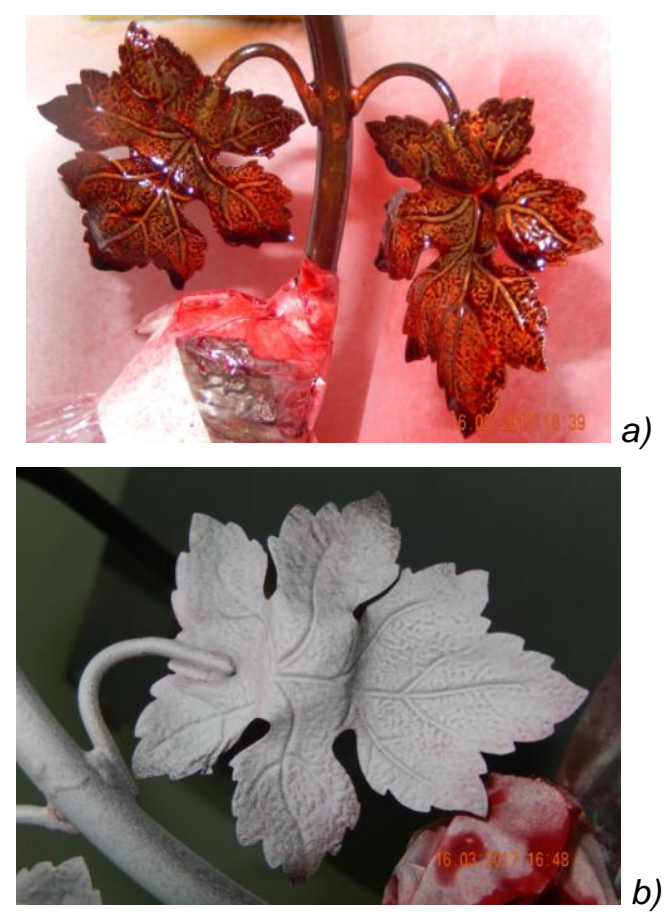

Figure 4. Two stages in penetrant testing after spraying with: a) activator and b) developer

Slika 4. Dve faze penetrantskog ispitivanja sa; a) aktivatorom $i$ b) razvijačem

\section{CRACKS AT LEAF}

The chemical composition of leaves is not determined, here is assumed that they were made from copper or copper alloy (probably brass), as a material with good plasticity. Here are registered cracks at leaves at locations but the total fracture still was not happened, Fig. 5.

Crack identifyied at leaf is not straight, see Figs. $4 \mathrm{~b}$ and 5 , it means that fracture if will be hapened than will not be fully brittle. Crack is disposed according to the periphery at flux melting zone. After solodification of flux and brazing of an alloy is finished, some residuals of unmolten flux were stayed - at the periphery of melting zone. What kind of flux is used, now it is not known. But, as known from the brazing technology, the flux composed from chlorides, fluorides, borates, etc., in its nature is chemicaly agresive and may produce also agressive compound(s) or intermetallic phases at brazed joint and/or surface arround.

After a period of time from XIX century, when brazing is done, and described inspections in nowdays, the presence of just one crack at brazed leaves is discovered, as evidented. The crack in this case lies in zone of flux residuals, after brazing is provided. 


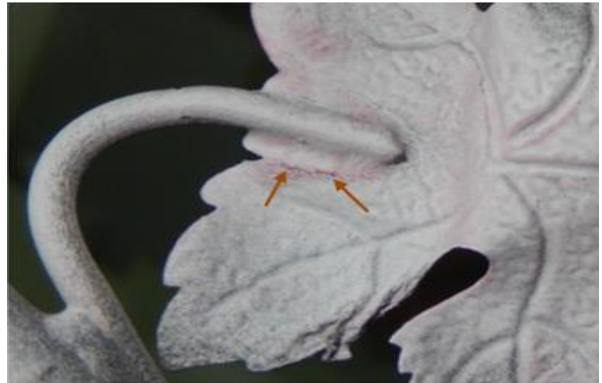

Figure 5. Enlarged view of discovered crack ( $\approx 6 \mathrm{~mm}$ in length) at leaf

Slika 5. Uvećan pogled na otkrivenu pukotinu (dužine $\approx 6 \mathrm{~mm}$ ) na listu

\section{DISCUSSION}

Thiny lines, at Fig. 3, have different origin: they were impressed into leaves by hammering $[6,15$, $16]$, but they do not represent any kind of cracks, as could be misconcluded from Figs. $4 \mathrm{~b}$ and 5 .

There are many heating methods available to accomplish brazing operations. The most common methods now are: torch/gas brazing, furnace, induction brazing, etc. According to the age when this desk lamp is made (XIX century), it is reliable to propose that brazing is done with torch, manually.

In general, braze alloys are made up of 3 or more metals to form an alloy with the desired properties. The filler metal for a particular application is chosen based on its ability to: wet the base metals, see Fig. $2 a$, and melt at a lower temperature than the base metals [7-10].

Fluxes, today, can be applied in any number of forms including flux paste, liquid, powder or premade brazing pastes that combine flux with filler metal powder. But, we don't know what kind of flux is used. Anyway, the flux must help to flow of molten metal and entering into the joint, Fig. 2a. Excess flux should be removed when the cycle is completed, because flux left in the joint may have led to generate the corrosion, and prevent next surface finishing operation(s) [8].

Fluxes are generally selected based on their performance on particular metals to be joined. To be effective, the flux must be chemically compatible with both the base metal and the filler metal being used.

In mechanical constructions the types of fracture usually are considered as: tough or brittle, but frequently is mixed type, as a consequence of fatigue or creep in material. Corrosion is also considered as a serious reason for damage or fracture at artistic parts[17,18]. The corrosion behavior during brazing has not found a wide explanation in production of artistic component(s). An obvious step for every fracture is crack appearance almost at the surface $[19,20]$, neither of its dimensions.
Brazing or soldering may be more corrosive than welding technology, what is explainable by greater chemical activity of used components during joining, as like $\mathrm{NH}_{4} \mathrm{Cl}$ or kind of fluoride, etc.

\section{CONCLUSION}

The components from observed desk lamp are produced by casting, hammering and brazing, and few components are mechanicaly attached.

Film obtained by X-ray transmision technique has shown the presence a kind of indications only at leaves. More sensitive testing techniques, penetrant testing, here is applied for better understanding the nature of registered irregularities.

A brazed components are composed from different phases with differing physical and chemical properties, specially at the interface between base metal and filler metal. The relevant factors for successfull brazing are the condition of the metal surface, it means the presence of oxides, grease or other coatings, further possible metalurgical and chemical reactions between parent and filler metals, particularly reactions with used flux and process atmosphere.

The origin of cracks at leaves could be considered as a result of corrodive action of chemical ressiduals from used flux, $\mathrm{NH}_{4} \mathrm{Cl}$, or kind of fluoride, etc. When brazing is complited than the flux residues has to be removed. Unremoving of such residues may have lead, as here, to corrosion progress and crack(s) appearance.

\section{Aknowledgement}

Chemical analysis and X-ray transmission inspection were done at Institute for welding, Belgrade, and penetrant testing by Techcon, Belgrade. In all provides experiments we are gratefull to their efforts and to Serbian Ministery of culture and informations under Projects 633-00-43/2016-02 and Ministery of education, science and Technological development under Project TR-34028.

\section{REFERENCES}

[1] F. Schweizer (1994) Bronze objects from like Sites, From Patina to "Biography", Ancient\&Historic Metals conservation and scientific research, The Getty conservation Institute, p. 33-50.

[2] B.Kočovski (1967) Metallurgy of Non-ferrous Metals, in Serbian, Faculty of Mining and Metallurgy, Bor, p. 28-174.

[3] Lj.Ivanić (2000) Casting, University of Belgrade, Technical Faculty Bor, p. 53-137.

[4] S.Marković, V.Radovanović, Ž.Kamberović (2005) Artistic Casting, in Serbian, Belgrade, Klasa d.o.o, p. 11-68.

[5] M.Barjanovskij, A.Dmitrovič, N.Intjakov, V.Čajka (1996) Handbook for technologists, in Russian, Minsk, Belarus, p. 47-205. 
[6] I.K.Suvorov (1973) Metal Working Processes, Moscow, Visšaya škola, p. 228-375.

[7] Ју.Ф.Шени, С.Н.Лоцманов (1984) Технологи ческиј процесс пајки металлических материалов, у приручнику: Справочник по пајке, Москва, Машиностроение, р.249-270.

[8] Z.Kovačević, Z.Karastojković, R.Perić (2011) How to avoid chemical agresive substances in waste waters from gold jewel production, 11. Inter. multidisciplinary scientific geoconference SGEM, Varna-Bulgaria, proceed. book, p. 405-410.

[9] Z.Karastojković, S.Polić, M.Srećković, N.llić, Z.V. Janjušević (2017) X-Ray transparent testing of leaves from an artistic desk lamp, Zaštita materijala, 58(2), 158-162.

[10] C.Calzaa, D.F.Oliveiraa, R.P.Freitasc, H.S. Rochaa, J.R.Nascimentoa, R.T.Lopesa (2015) Analysis of Sculptures Using XRF and X-ray Radiography, Radiation Physics and Chemistry, 116, 326-331.

[11] I.Aničin, A.Fertilio, M.Nikolić (1988) Radiography Principles and Testing Methods, Belgrade, Institut za nuklearne nauke Vinča, p. 91-182.

[12] R.E. Shoy Jr, M.S. van Lysel, M.J. Yaffe (1995) Xray Equipment, Handbook Biomedical Engineering, Hartford-Connecticut/USA, CRS Press, IEEE Press, p. $953-972$

[13] J.Bassett (2005) An Opportunity taken: the project design for a technical study of 26 bronzes in the exhibition adriaen de vries: imperial sculptor at the J. Paul Getty museum, Objects specialty group postprints, volume 9, pp. 68-78.

[14] R.Van Langh, E.Lehmann, S.Hartmann, A. Kaestner, F. Scholten (2009) The Study of Bronze Statuettes with the Help of Neutron-imaging Techniques, Analytical and Bioanalytical Chemistry, 395(7), 1949-1959.

[15] K.N.Bogojavljenskij, V.V.Žolobov (1973) Deformation of Non-ferrous Metals and Alloys, Moscow, Metallurgiya, p. 217-434.

[16] G.I.Beljčenko, S.I.Gubenko (1987) Principles of Metallography and Working Processes of Steels, Kiev-Doneck, Višča škola, p. 42-119.

[17] S.Petrić, S.Polić, D.Jovanović, N.Ilić, V.Živković, V. Džikić (2015) Conservation of Silver Belt Type „Mramorac“, Centralni institut za konzervaciju u Beogradu i Zavičajni muzej Jagodina, p.5-27.

[18] Z.Karastojković (2016) Surface Protection of Metals, Visoka tehnička škola strukovnih studija Novi Beograd, p. 79-100.

[19] A.M.Wasserman, V.A.Danilkin, O.S.Korobov (1985) Methods of Control and Testing of Light Metals, Moscow, Metallurgiya, p. 61-64.

[20] J.C.Vickerman (1997) Surface Analisis - The Principal Techniques, Chichester-England, John Wiley\&Sons, p. 46-49; 371-389.

\title{
IZVOD
}

\section{KOROZIONE PUKOTINE OD ZAOSTALOG TOPITELJA POSLE LEMLJENJA TANKIH LISTOVA NA JEDNOJ UMETNIČKOJ STOLNOJ LAMPI}

\begin{abstract}
Izrada jednog umetničkog dela obično uključuje brojne različite tehnologije. To podrazumeva da je za razumevanje eventualno prisutnih nepravilnosti potrebno znati puno tehničkih detalja. Tehnologija lemljenja je jedna od njih, ispitivanje integriteta, takođe. Tehnologija lemljenja, uopšte, se razvijala na empirijski način, uglavnom pokušajima i greškama. Osnovnu teškoću čini realna situacija, koja je veoma složena, usled prisustva velikog broja uticajnih veličina, neke od njih se ne mogu lako prepoznati. Veliki problem je pojava pukotina u periodu posle čišćenja, tj. po završetku lemljenja, a to znači nekada posle više godina ili decenija. Dobar zalemljeni spoj mora biti valjano fizički i hemijski spojen.

Jedna od primenljivih metoda ispitivanja je radiografsko ispitivanje, kada debljina ispitivanih delova obično ne predstavlja problem. Ovde izvedena radiografska ispitivanja su nagovestila prisustvo nekih indikacija samo na listovima. Penetranstsko ispitivanje je sledeći korak za ispitivanje površine. Registrovanje indikacija $i$ njihovo lociranje su neophodni koraci u svakom daljem pristupu u cilju uklanjanja takvih diskontinuiteta. Izbor metode reparacije uvek je poseban problem, dakako u celoj tehnici, a posebno na osetljivim umetničkim predmetima. Svako delovanje $u$ reparaciji ili restauraciji može dovesti do manje ili više vidljivih tragova. Neodgovarajuća delovanja mogu dovesti do manje ili više vidljivih tragova. Ovde je pokazana jedna nepravilnost (pukotina) na zalemljenom listu, na jednoj umetničkoj stonoj lampi.
\end{abstract}

Ključne reči: umetnički predmet, radiografsko\&penetrantsko ispitivanje, koroziona pukotina.

Naučni rad

Rad primljen: 15. 05. 2018.

Rad prihvaćen: 17. 06. 2018.

Rad je dostupan na sajtu: www.idk.org.rs/casopis

(c) 2018 Authors. Published by Engineering Society for Corrosion. This article is an open access article distributed under the terms and conditions of the Creative Commons Attribution 4.0 International license (https://creativecommons.org/licenses/by/4.0/) 